\title{
Obesity, food insecurity, and depression among females
}

\author{
Manik Ahuja ${ }^{1 *}\left(\mathbb{D}\right.$, Thiveya Sathiyaseelan ${ }^{2}$, Rajvi J. Wani ${ }^{3}$ and Praveen Fernandopulle ${ }^{4}$
}

\begin{abstract}
Background: Nutritional psychiatry is an emerging field of research and it is currently exploring the impact of nutrition and obesity on brain function and mental illness. Prior studies links between obesity, nutrition and depression among women. However, less is known how food insecurity may moderate that relationship.

Methods: Data were employed from the Collaborative Psychiatric Epidemiology Surveys (CPES), 2001-2003. Two logistic regression models were Logistic regression was used to determine the association between obesity, gender, food insecurity, and past year Major Depressive Disorder (MDD). We then stratified by gender, and tested the association between obesity and past year MDD, and if food insecurity moderated the association.

Results: Obesity was associated with an increased risk for past year Major Depressive Disorder (MDD) among females ( $A O R=1.35 ; 95 \% \mathrm{Cl} 1.17-1.55$ ) and was not associated among males ( $A O R=1.07 ; 95 \% \mathrm{Cl}, 0.86-1.32$ ). Women who reported that reported both obesity and food insecurity reported higher odds of past year MDD episode $(\mathrm{AOR}=3.16 ; 95 \% \mathrm{Cl}, 2.36-4.21$, than women who did not report food insecurity $(\mathrm{AOR}=1.08 ; 95 \% \mathrm{Cl}$, 1.02 1.38).

Conclusion: With rising rates of mental health problems, females should be closely monitored to understand how poor diets, food insecurity, and obesity play a role in mental health outcomes. It is recommended that clinicians and treatment providers consider the patient's diet and access to nutritious foods when conducting their assessment.
\end{abstract}

Keywords: Food insecurity and mental health, Obesity and depression, Food insecurity and obesity among women, Obesity and mental health disorders

\section{Background}

Nutritional psychiatry is an emerging field of research and it is currently exploring the impact of nutrition on brain function and mental illness. Nutrition has been vastly overlooked as a contributor to mental health problems [1]. The prevalence of obesity in the adult population is a global health challenge [2], and is associated with adverse outcomes including chronic disease and mortality. Obesity is defined as Body Mass Index (BMI) of 30 or more, and known to highly prevalent

\footnotetext{
* Correspondence: ahujam@etsu.edu

${ }^{1}$ College of Public Health, East Tennessee State University, 41B Lamb Hall, Johnson City, TN 37614, USA

Full list of author information is available at the end of the article
}

among individuals who consume inexpensive, caloriedense foods and engage in lower levels of physical activity [3-6].

Several studies have found associations between obesity and mental health problems [7-9]. Simon and his colleagues (2006) concluded that obesity is associated with approximately $25 \%$ increase in odds of mood and anxiety disorders [10]. A large cross-sectional study conducted by McMartin et al. [11] reported consistent inverse relationships between fruit and vegetable intake and major depressive disorder (MDD) [12]. The associations between dietary patterns and depression remains significant and strong epidemiological evidence suggests that poor diet can have a negative effect on mental

(c) The Author(s). 2020 Open Access This article is licensed under a Creative Commons Attribution 4.0 International License, which permits use, sharing, adaptation, distribution and reproduction in any medium or format, as long as you give appropriate credit to the original author(s) and the source, provide a link to the Creative Commons licence, and indicate if changes were made. The images or other third party material in this article are included in the article's Creative Commons licence, unless indicated otherwise in a credit line to the material. If material is not included in the article's Creative Commons licence and your intended use is not permitted by statutory regulation or exceeds the permitted use, you will need to obtain permission directly from the copyright holder. To view a copy of this licence, visit http://creativecommons.org/licenses/by/4.0/ The Creative Commons Public Domain Dedication waiver (http://creativecommons.org/publicdomain/zero/1.0/) applies to the data made available in this article, unless otherwise stated in a credit line to the data. 
health disorders. Implementing changes to the diet is gaining popularity in life sciences as it provides structural, functional, and biochemical roles of macro- and micronutrients in mental well-being [13].

Studies have revealed positive associations between obesity and depressive symptoms among women and either negative or no associations among men $[8,10,14$, 15]. Studies show there are significant gender disparities, as women are nearly twice as likely as men to suffer from mental illness $[16,17]$. According to data from the National Health and Nutrition Examination Survey (NHANES), the rate of obesity for adult women is over $40 \%$ in the U.S. [18], and is expected to continue to rise over the next 30 years [19], placing even more women at risk. In addition, obesity and depression both carry an increased risk for other diseases such as cardiovascular disease [20]. There are still more gaps to fill when it comes to understanding obesity and mental health among women. The dietary intake in the female population in conjunction with the biochemical measurements of diet can aid in distinguishing the cause of MDD, whether it is caused by reduced intake, altered metabolism or enzymatic function [21].

For many there is limited access to nutritious food as it can be costly, therefore, individuals often consume poor diets. As food insecurity impacts 1 in 7 people in the United States and it can also be a contributor to the rising obesity rate [22]. Prior studies have found associations between food insecurity and poor mental health among females [23, 24]. To date, no studies have investigated how food insecurity moderates the effects of obesity and depression particularly among women. To current study addresses these gaps using a nationally representative, ethnically diverse sample from the United States.

\section{Methods \\ Data}

The current study used secondary data from the $\mathrm{Na}$ tional Co-Morbidity Survey Replication (NCS-R), National Survey of American Life (NSAL), and National Latino and Asian American Study (NLAAS), as these were presented in the Collaborative Psychiatric Epidemiology Surveys (CPES), 2001-2003. CPES was designed to collect representative samples of majority and minority adult populations in the U.S., with oversampling of race/ ethnic minorities [25]. The study employed probability sampling techniques to identify 252 geographic areas across the U.S., where adults were selected from each eligible household [25]. For specific study design see [26-28]. The final sample included 20,013 respondents (aged > $=18)$, who self-identified as female $(n=11,463$; $57.3 \%)$, male $(n=8550 ; 42.7 \%)$, non-Hispanic white $(n=$ 7.587; $37.9 \%)$, black $(n=6.281 ; 31.1 \%)$, Latino $(n=3.620$;
$18.1 \%)$, and Asian ( $n=2.284 ; 11.4 \%)$. The CPES data were obtained from the Inter-university Consortium for Political and Social Research (Ann Arbor, MI). All procedures that involved human subjects, including consent from all participants 18 years of age and older, were approved by the Institutional Review Board at the University of Michigan [29].

\section{Methods}

\section{Data}

The current study used data from the National CoMorbidity Survey Replication (NCS-R), National Survey of American Life (NSAL), and National Latino and Asian American Study (NLAAS), as these were presented in the Collaborative Psychiatric Epidemiology Surveys (CPES), 2001-2003. The final sample included 20,013 respondents (with complete information on all variables in the analyses) who self-identified as female $(n=11,463 ; 57.3 \%)$ and male $(n=8550 ; 42.7 \%)$, nonHispanic white $(n=7.587 ; 37.9 \%)$, Black $(n=6.281$; $31.1 \%)$, Latino $(n=3.620 ; 18.1 \%)$, and Asian $(n=2.284$; $11.4 \%)$.

\section{Measures}

The primary outcome of interest in the current study is report of past year Major Depressive Disorder (MDD) episode. Past year episode of MDD was assessed based on lifetime report of MDD, as measured by the diagnostic interview of World Mental Health Initiative version of the composite International Diagnostic Interviews, which is based on DSM-IV criteria (APA [30]).

Obesity was coded binary, with participants who reported a BMI level $\geq 30 \mathrm{~kg} /$ meter squared as 1 , and BMI level $<30$ as 0 . BMI was determined participant from self-reports of height and weight. This coding of this measure is consistent with prior studies on obesity and depression (Gavin et al. [31]). Respondents were classified as either obese (BMI $\geq 30 \mathrm{~kg} /$ meter squared $\left[\mathrm{kg} / \mathrm{m}^{2}\right]$ ) or non-obese (BMI $18.5-29.9 \mathrm{~kg} / \mathrm{m}^{2}$ ) both for consistency with previous research and a lack of evidence suggesting that overweight status is statistically associated with depression. Food insecurity was based on the following question 'In past yr-how often not enough money to buy food?', and coded binary with 1 representing any report of food insecurity in the past year. This variable 'food insecurity' was selected based on its definition of having inconsistent access to adequate food because of limited financial and other resources [32], and has been applied in prior studies [33-35].

\section{Covariates}

We adjusted for income, education, age, and race. Income was coded as 1 representing low income of $<\$ 30$, 000 , and 0 representing income $>=\$ 30,000$. Education 
was coded as <high school as 1 , and 0 represents graduating high school or more than high school education. Race was coded based on self-report of race, and dummy coded into 4 variables including Black, Latino, Asian, with White representing the reference group.

\section{Data analysis}

Two separate logistic regression models were run. In the first analysis, logistic regression was used to assess whether the obesity-depression association varied by gender. Interaction terms between obesity and gender were created and re-parameterized as 'obesity and male' and 'obesity and female'. In the second analysis, we stratified by gender to assess whether there was a moderating effect of food insecurity. Data were reparameterized as report of 'obesity and food insecurity', and 'obesity and no report of food insecurity', to assess whether food insecurity moderated the relationship between obesity and past year depression among females.

\section{Results}

Table 1 shows descriptive statistics for the sample. Overall, $(n=4999) ; 25.1 \%$ of participants reported obesity at BMI > $=30$, overall $(n=1543 ; 7.7 \%)$ participants reported past year MDD, and ( $n=1942 ; 9.7 \%)$ reported past year food insecurity.

In Table 2, we examined the association between obesity and 12-month MDD. In our fully adjusted model examining the main effects, obesity $(\mathrm{AOR}=1.26$; $95 \% \mathrm{CI}$ $1.12-1.41$ ), male gender (AOR $=0.57$; 95\% CI $0.51-$ 0.64 ), and food insecurity ( $\mathrm{AOR}=3.29$; 95\% CI 2.82 3.83) were associated with past year MDD. We tested for interactions for gender and obesity, and found that females who reported obesity (AOR $=1.35$; 95\% CI 1.17 1.55) reported higher odds of past year MDD than males $(\mathrm{AOR}=1.07 ; 95 \% \mathrm{CI}, 0.86-1.32)$.

In Table 3, we used logistic regression to examine the effect of food insecurity as a moderating variable with obesity and MDD among females. We found that obese participants that reported food insecurity $(\mathrm{AOR}=3.16$; 95\% CI, 2.36-4.21) had significant higher odds than participants who did not report food insecurity $(\mathrm{AOR}=$ 1.08; 95\% CI, 1.02-1.38).

\section{Discussion}

This study reveals the association between obesity and depression and the moderating role of food insecurity that exists among women using a nationally representative sample from the United States. The study found an association between obesity and past year episode of MDD among women, but not men, which is consistent with prior research $[8,36,37]$. Depression may be associated with obesity due to factors such as negative body image, and low self-esteem [38, 39], which is more
Table 1 Sample characteristics and prevalence of BMl, food insecurity, and major depressive disorder $(N=20,013)$

\begin{tabular}{|c|c|}
\hline & $\mathrm{N}(\%)$ \\
\hline \multicolumn{2}{|l|}{ Sex } \\
\hline Female & $11,463(57.3)$ \\
\hline Male & $8550(42.7)$ \\
\hline \multicolumn{2}{|l|}{ Race } \\
\hline White & 7587 (37.9) \\
\hline Black & $6238(31.1)$ \\
\hline Latino & $3620(18.1)$ \\
\hline Asian & $2284(11.4)$ \\
\hline \multicolumn{2}{|l|}{ Education $^{a}$} \\
\hline$<$ High school & $4112(20.6)$ \\
\hline Graduated High School & 5919 (29.6) \\
\hline Some College & $5263(26.3)$ \\
\hline Graduated College & 4719 (23.6) \\
\hline \multicolumn{2}{|l|}{ Household income } \\
\hline$<\$ 30,000$ & $10,513(52.5)$ \\
\hline$\$ 30,000-\$ 74,999$ & $5944(29.7)$ \\
\hline$>=\$ 75,000$ & $3556(17.8)$ \\
\hline \multicolumn{2}{|l|}{ BMl } \\
\hline < 18.5: Underweight & $582(2.9)$ \\
\hline 18-5-24.9: Healthy weight & $7285(36.4)$ \\
\hline 25.0-29.9: Overweight & $6576(32.9)$ \\
\hline$>=30.0$ Obesity & $4999(25.1)$ \\
\hline Food insecurity & $1942(9.7)$ \\
\hline Major depressive disorder ${ }^{b}$ & $1942(9.7)$ \\
\hline Lifetime episode & $3241(16.2)$ \\
\hline Past year episode & $1543(7.7)$ \\
\hline
\end{tabular}

$N$ Number, BMI Body Mass Index

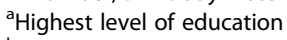

${ }^{b}$ DSM-IV

prevalent among women [40]. There are many potential factors that contribute to higher rates of depression among women, and both obesity and food insecurity are important factors to consider.

We looked at differences within women and found that women with high BMI levels $(>=30)$ and who reported food insecurity were at a significantly higher risk for depression than women who did not report food insecurity. Food insecurity is an important factor of health and nutrition outcomes [41]. Food insecurity may refer to individuals who are micronutrient deficient, or undernourished [42]. Food insecurity is also the uncertainty of acquiring nutritious food in a safe and socially acceptable manner Food insecurity has been found to be associated with obesity and unhealthy dietary patterns, both of which have negative health outcomes [43]. 
Table 2 Results of logistic regression analyses predicting past year major depressive disorder episode

\begin{tabular}{|c|c|}
\hline & AOR $(95 \% \mathrm{Cl})$ \\
\hline \multicolumn{2}{|l|}{ Main effects } \\
\hline Non-Hispanic White & Ref \\
\hline Black & $0.66(0.58-0.75)^{*}$ \\
\hline Latino & $0.61(0.52-0.71)^{*}$ \\
\hline Asian & $0.36(0.29-0.44)^{*}$ \\
\hline Male gender & $0.57(0.51-0.64)^{*}$ \\
\hline Female gender & Ref \\
\hline Age & $0.98(0.98-0.99)^{*}$ \\
\hline Education: < High school & $1.34(1.17-1.53)^{*}$ \\
\hline Income: $<\$ 30,000$ per year & $0.84(0.75-0.93)^{*}$ \\
\hline Food insecurity & $3.29(2.82-3.83)^{*}$ \\
\hline Obesity & $1.26(1.12-1.41)^{*}$ \\
\hline \multicolumn{2}{|l|}{ Interactions } \\
\hline Obesity* female & $1.35(1.17-1.55)^{*}$ \\
\hline Obesity*male & $1.07(0.86-1.32)$ \\
\hline
\end{tabular}

Given the increasing number of female-headed households, and the lower wages of women compared to men, women need special consideration in discussions of food insecurity and their effect on health [44]. Food insecurity is known to disproportionally affect women. A crosssectional study using data from the nationally representative Continuing Survey of Food Intakes by Individuals, found that food insecurity was associated to overweight status in women in the United States, but not men [45]. In another study using data from a nationally representative sample, Hanson et al. [43] found that low food security was associated with being obese among women [46].

The findings of the study reveal that there are severe implications associated with food insecurity, particularly with mental health among women. Targeted interventions to

Table 3 The association of obesity, food insecurity and past year major depressive disorder (MDD) episode among females

\begin{tabular}{|c|c|}
\hline Variable & AOR $(95 \% \mathrm{Cl})$ \\
\hline Non-Hispanic White & Ref \\
\hline Black & $0.63(0.54--0.73)^{*}$ \\
\hline Latino & $0.78(0.75-1.00)$ \\
\hline Asian & $0.40(0.30-0.53)^{*}$ \\
\hline Age & $0.98(0.97-0.98)^{*}$ \\
\hline Education: < High school & $1.44(1.17-1.78)^{*}$ \\
\hline Income: $<\$ 30,000$ per year & $0.88(0.77-1.01)$ \\
\hline Obesity*food insecurity & $3.16(2.36-4.21)^{*}$ \\
\hline Obesity*no report of food insecurity & $1.08(1.02-1.38)^{*}$ \\
\hline
\end{tabular}

increase awareness about safe, nutritious foods among women should be considered. Nutrition education plays an important role in food security [43]. For example, one study found that nutrition education was shown to improve the food security of low-income individuals who participated in the Expanded Food and Nutrition Education Programs in two states [46]. Food-insecure women have lower intakes of healthy foods such as fruits and vegetables and other nutrients compared with food-secure women [47, 48], It is important that women be given special consideration, and policy measures to improve access to safe, nutritious foods for women should be considered. These include public assistance programs, and other subsidies offered to women, which may prevent or reduce their risk of feeling food insecure. Given the current economic state, and the COVID-19 pandemic, women as well as children could feel the majority of the negative effects of food insecurity [49].

The results from this study should not be interpreted without considering the limitations. Firstly, the causeeffect relationships cannot be established in this study, given cross-sectional data were used. Second, was that surveys from non-English speaking Latinos and Asians were not collected in the NCS-R data. Third, depression diagnosis was based on DSM-IV criteria, as DSM-5 is currently implemented. There have been changes to diagnostic criteria, including the dropping of the Global Assessment of Functioning (GAF) scale, which was used in DSM-IV. This may pose a challenge among clinicians, who are using DSM-5 diagnosis to treat depression. However, the changes from DSM-IV to DSM-5 are not likely to significantly impact prevalence rates, and not affect the characteristics of diagnoses [50]. Fourth, BMI was calculated using self-reported height and weight by each participant. Prior studies have found that it is common for individuals to inaccurately report their height and weight, that include both over and underreporting measurements [51]. There are known discrepancies in these measurements when they are taken by a trained professional [51].

\section{Conclusion}

The impact of nutrition and obesity on mental health and overall fitness is being reported and documented. To fill the gap in the current knowledge and literature base, this study demonstrates an association between obesity and mental health outcomes by gender while evaluating the effect of food insecurity. It is recommended that clinicians allocate time in discussing vital nutrients when formulating a treatment plan, as diet can augment the medications used to treat and prevent various chronic diseases. It is also vital for health providers to also consider food insecurity in their assessment as it makes it difficult for patients to adhere to a diet that supports their diagnosis. 


\section{Abbreviations}

BMl: Body mass index; DHA: Docosahexaenoic acid; MDD: Major Depressive Disorder; PUFA: Polyunsaturated fatty acids; WHO: World Health Organization

\section{Informed consent}

No primary data collection was conducted.

\section{Authors' contributions}

MA designed the study, performed data analysis and interpretation, and prepared the manuscript. TS designed the study, conducted a literature search, and interpretation of findings in the drafted manuscript. RW participated in the design of the study, assisted and revised the draft manuscript. PF participated in the design of the study, assisted and revised the draft manuscript. All authors approved the final manuscript.

\section{Funding}

The author(s) received no financial support for the research, authorship, and/ or publication of this article.

\section{Availability of data and materials}

The datasets used and/or analysed during the current study are available from the corresponding author on reasonable request.

\section{Ethics approval and consent to participate}

Secondary analysis was conducted from the publicly available Collaborative Psychiatric Epidemiology Surveys (CPES), 2001-2003 dataset. Data has no identifying information. https://www.icpsr.umich.edu/icpsrweb/ICPSR/ studies/20240

\section{Competing interests}

The authors declare that they have no conflict of interest.

\section{Author details}

${ }^{1}$ College of Public Health, East Tennessee State University, 41B Lamb Hall, Johnson City, TN 37614, USA. ${ }^{2}$ Aureus School of Medicine, Oranjestad, Aruba. ${ }^{3}$ College of Public Health, University of Nebraska Medical Center, Omaha, NE, USA. ${ }^{4}$ Psychiatry and Behavioral Sciences Department, East Tennessee State University, Johnson City, TN, USA.

Received: 30 May 2020 Accepted: 2 September 2020 Published online: 17 September 2020

\section{References}

1. Stefanska $E$, et al. Assessment of dietary habits and nutritional status of depressive patients, depending on place of residence. Ann Agric Environ Med. 2017; https://doi.org/10.5604/12321966.1233554.

2. Rush EC, Yan MR. Evolution not revolution: nutrition and obesity. Nutrients. 2017:9(5):1-8 https://doi.org/10.3390/nu9050519.

3. Drewnowski A, Specter SE. Poverty and obesity: the role of energy density and energy costs. Am J Clin Nutr. 2004; https://doi.org/10.1093/ajcn/79.1.6.

4. Pereira MA, et al. Fast-food habits, weight gain, and insulin resistance (the CARDIA study): 15-year prospective analysis. Lancet. 2005; https://doi.org/10. 1016/S0140-6736(04)17663-0.

5. Block JP, Scribner RA, Desalvo KB. Fast food, race/ethnicity, and income: a geographic analysis. Am J Prev Med. 2004; https://doi.org/10.1016/j.amepre. 2004.06.007.

6. Frank LD, Andresen MA, Schmid TL. Obesity relationships with community design, physical activity, and time spent in cars. Am J Prev Med. 2004; https://doi.org/10.1016/jamepre.2004.04.011.

7. Stunkard AJ, Faith MS, Allison KC. Depression and obesity. Biol Psychiatry. 2003; https://doi.org/10.1016/S0006-3223(03)00608-5.

8. Carpenter KM, Hasin DS, Allison DB, Faith MS. Relationships between obesity and DSM-IV major depressive disorder, suicide ideation, and suicide attempts: results from a general population study. Am J Public Health. 2000; https://doi.org/10.2105/AJPH.90.2.251.

9. McElroy SL, Kotwal R, Malhotra S, Nelson EB, Keck PE, Nemeroff CB. Are mood disorders and obesity related? A review for the mental health professional. J Clin Psychiatry. 2004; https://doi.org/10.4088/JCP.v65n0507.

10. Simon GE, et al. Association between obesity and psychiatric disorders in the US adult population. Arch Gen Psychiatry. 2006; https://doi.org/10.1001/ archpsyc.63.7.824.
11. McMartin SE, Jacka FN, Colman I. The association between fruit and vegetable consumption and mental health disorders: evidence from five waves of a national survey of Canadians. Prev Med. 2013;56(3-4):225-30. https://doi.org/10.1016/j.ypmed.2012.12.016.

12. Jacka FN, et al. Association of western and traditional diets with depression and anxiety in women. Am J Psychiatry. 2010; https://doi.org/10.1176/appi. ajp.2009.09060881.

13. Begdache L, Chaar M, Sabounchi N, Kianmehr H. Assessment of dietary factors, dietary practices and exercise on mental distress in young adults versus matured adults: a cross-sectional study. Nutr Neurosci. 2019; https:// doi.org/10.1080/1028415X.2017.1411875.

14. Palinkas LA, Wingard DL, Barrett-Connor E. Depressive symptoms in overweight and obese older adults: a test of the 'jolly fat' hypothesis. J Psychosom Res. 1996; https://doi.org/10.1016/0022-3999(95)00542-0.

15. Onyike CU, Crum RM, Lee HB, Lyketsos CG. Eaton WW. Is obesity associated with major depression? Results from the third National Health and nutrition examination survey. Am J Epidemiol. 2003; https://doi.org/10.1093/aje/ kwg275.

16. Yu S. Uncovering the hidden impacts of inequality on mental health: a global study. Transl Psychiatry. 2018; https://doi.org/10.1038/s41398-0180148-0.

17. Weissman MM, Olfson M. Depression in women: implications for health care research. Science. 1995; https://doi.org/10.1126/science.7638596.

18. Flegal KM, Kruszon-Moran D, Carroll MD, Fryar CD, Ogden CL. Trends in obesity among adults in the United States, 2005 to 2014. JAMA. 2016; https://doi.org/10.1001/jama.2016.6458.

19. Agha M, Agha R. The rising prevalence of obesity. Int J Surg Oncol. 2017; https://doi.org/10.1097/ij9.0000000000000017.

20. Penninx BWJH, et al. Depression and cardiac mortality: results from a community-based longitudinal study. Arch Gen Psychiatry. 2001; https://doi. org/10.1001/archpsyc.58.3.221.

21. Bodnar LM, Wisner KL. Nutrition and depression: implications for improving mental health among childbearing-aged women. Biol Psychiatry. 2005; https://doi.org/10.1016/j.biopsych.2005.05.009.

22. Coleman-jensen A, et al. Household food security in the United States in 2017, ERR-256. United States Dept Agric. 2018

23. Maynard M, Andrade L, Packull-McCormick S, Perlman CM, Leos-Toro C, Kirkpatrick SI. Food insecurity and mental health among females in highincome countries. Int J Environ Res Public Health. 2018; https://doi.org/10. 3390/ijerph15071424.

24. Jones AD. Food insecurity and mental health status: a global analysis of 149 countries. Am J Prev Med. 2017; https://doi.org/10.1016/j.amepre.2017.04.008

25. Lo CC, Cheng TC. Racial/ethnic differences in access to substance abuse treatment. J Health Care Poor Underserved. 2011; https://doi.org/10.1353/ hpu.2011.0054.

26. Alegria $\mathrm{M}$, et al. Considering context, place and culture: the National Latino and Asian American Study. Int J Methods Psychiatr Res. 2004; https://doi. org/10.1002/mpr.178.

27. Heeringa SG, Wagner J, Torres M, Duan N, Adams T, Berglund P. Sample designs and sampling methods for the collaborative psychiatric epidemiololgy studies (CPES). Int J Methods Psychiatr Res. 2004; https://doi. org/10.1002/mpr.179.

28. Jackson JS, et al. The National Survey of American life: a study of racial, ethnic and cultural influences on mental disorders and mental health. Int J Methods Psychiatr Res. 2004; https://doi.org/10.1002/mpr.177.

29. Pennell BE, et al. The development and implementation of the National Comorbidity Survey Replication, the National Survey of American Life, and the National Latino and Asian American Survey. Int J Methods Psychiatr Res. 2004; https://doi.org/10.1002/mpr.180.

30. American Psychiatric Association. Diagnostic and statistical manual of mental disorders source information. Am Psychiatr Assoc. 1994.

31. Gavin AR, Rue T, Takeuchi D. Racial/ethnic differences in the association between obesity and major depressive disorder: findings from the comprehensive psychiatric epidemiology surveys. Public Health Rep. 2010; https://doi.org/10.1177/003335491012500512.

32. Coleman-Jensen A, Rabbitt MP, Gregory C, Singh A. Household food security in the United States in 2014. In: U.S. household food security: statistics and analysis for 2014; 2016.

33. Gundersen C, Ziliak JP. Food insecurity and health outcomes. Health Aff. 2015; https://doi.org/10.1377/hlthaff.2015.0645. 
34. Gundersen C, Ziliak JP. Food insecurity research in the United States: where we have been and where we need to go. Appl Econ Perspect Policy. 2018; https://doi.org/10.1093/aepp/ppx058.

35. Radimer KL, Olson CM, Greene JC, Campbell CC, Habicht JP. Understanding hunger and developing indicators to assess it in women and children. J Nutr Educ. 1992; https://doi.org/10.1016/S0022-3182(12)80137-3.

36. Askari J, et al. The relationship between obesity and depression. Procedia Soc Behav Sci. 2013; https://doi.org/10.1016/j.sbspro.2013.06.649.

37. Istvan J, Zavela K, Weidner G. Body weight and psychological distress in NHANES I. Int J Obes. 1992.

38. Strauss RS. Childhood obesity and self-esteem. Pediatrics. 2000; https://doi. org/10.1542/peds.105.1.e15.

39. Strauss RS, Pollack HA. Social marginalization of overweight children. Arch Pediatr Adolesc Med. 2003; https://doi.org/10.1001/archpedi.157.8.746.

40. Magee W, Upenieks L. Gender differences in self-esteem, unvarnished selfevaluation, future orientation, self-enhancement and self-derogation in a $U$. S. national sample. Pers Individ Differ. 2019; https://doi.org/10.1016/j.paid. 2019.05.016.

41. Pinstrup-Andersen P. Food security: definition and measurement. Food Secur. 2009; https://doi.org/10.1007/s12571-008-0002-y.

42. Ivers LC, Cullen KA. Food insecurity: special considerations for women. Am J Clin Nutr. 2011; https://doi.org/10.3945/ajcn.111.012617.

43. Morales ME, Berkowitz SA. The relationship between food insecurity, dietary patterns, and obesity. Curr Nutr Rep. 2016; https://doi.org/10.1007/s13668016-0153-y.

44. Townsend MS, Peerson J, Love B, Achterberg C, Murphy SP. Food insecurity is positively related to overweight in women. J Nutr. 2001; https://doi.org/ 10.1093/jn/131.6.1738

45. Hanson KL, Sobal J, Frongillo EA. Gender and marital status clarify associations between food insecurity and body weight. J Nutr. 2007; https:// doi.org/10.1093/jn/137.6.1460

46. Dollahite J, Olson C, Scott-Pierce M. The impact of nutrition education on food insecurity among low-income participants in EFNEP. Fam Consum Sci Res J. 2003; https://doi.org/10.1177/1077727X03032002003.

47. Mclntyre L, Tarasuk V, Li TJ. Improving the nutritional status of food-insecure women: first, let them eat what they like. Public Health Nutr. 2007; https:// doi.org/10.1017/S1368980007702902.

48. Tarasuk VS. Household food insecurity with hunger is associated with women's food intakes, health and household circumstances. J Nutr. 2001; https://doi.org/10.1093/jn/131.10.2670.

49. The Lancet Global Health. Food insecurity will be the sting in the tail of COVID-19. Lancet Glob Health. 2020; https://doi.org/10.1016/S2214109X(20)30228-X.

50. Substance Abuse and Mental Health Services Administration. DSM-5 changes: implications for child serious emotional disturbance. 2016.

51. Olfert MD, et al. Self-reported vs. measured height, weight, and BMI in young adults. Int J Environ Res Public Health. 2018; https://doi.org/10.3390/ ijerph15102216.

\section{Publisher's Note}

Springer Nature remains neutral with regard to jurisdictional claims in published maps and institutional affiliations.

Ready to submit your research? Choose BMC and benefit from:

- fast, convenient online submission

- thorough peer review by experienced researchers in your field

- rapid publication on acceptance

- support for research data, including large and complex data types

- gold Open Access which fosters wider collaboration and increased citations

- maximum visibility for your research: over $100 \mathrm{M}$ website views per year

At $\mathrm{BMC}$, research is always in progress.

Learn more biomedcentral.com/submissions 